these fractions to the concentrate. It is possible to concentrate the flavour from five to ten times in this way.

From this it is but a step to the reinforcement of natural flavours by the addition of carefully chosen substances. Such reinforced flavours are frequently used in table jellies or chocolate centres. It is, however, not always possible to use such flavouring materials, either owing to the unsuitability of the base to be flavoured, as in boiled sweets, or to the fact that the required flavour cannot be obtained from natural sources. It is then necessary to employ a compounded or 'synthetic' flavour in a suitable volatile solvent. The development of such flavours, which may consist of mixtures of a considerable number of components, is an art similar to that of the perfumer and calls for considerable skill and experience. To continue the parallel, just as there are good and crude perfumes, so there are variations in flavours and correct and incorrect methods of using them.

The use of added flavour for the purpose of concealing imperfections cannot, of course, be too severely condemned, and the lavish 'splashing in' of crude and unnatural flavours is also objectionable, but otherwise there can be no question of disapproving of any step that can add to the attractiveness and palatability of our food, an object which has been one of man's prime concerns throughout the ages.

The author wishes to thank the Directors of J. Lyons and Co. for permission to make this communication.

\title{
REFERENCES
}

Barnard, H. E. (I9II). Chem. Engr, I2, I04.

Bennett, A. H. \& Donovan, F. K. (1943). Analyst, 68, 140.

Power, F. B. \& Chesnut, V. K. (1921). F. Amer. chem. Soc. 43, 174I.

Stadtman, E. R., Barker, H. A., Haas, V., Mrak, E. M. \& MacKinney, G. (1946). Industr. Engng Chem. (Industr. ed.), 38, 324 .

\section{Nutritional Aspects of the Chemical Preservation, Colouring and Flavouring of Fruit and Vegetables}

By L. C. Baker, F. Lyons and Co. Ltd., Cadby Hall, London

I propose to deal briefly with the nutritional aspects of the chemical preservation, colouring and flavouring of fruit and vegetable products.

\section{Use of preservatives in fruit pulp and fruit drinks}

Fruit preserved for jam-making and other purposes by means of sulphur dioxide is known as fruit pulp; for technical reasons it is necessary to add a little water as well as preservative. The amounts of water and preservative added are limited by Government Order S.R. and O. 1944 to: (I) 3 pt. of preservative and r.25.gal. of water/cwt. of cooked pulp of black currant, red currant, white currant, gooseberry, plum and apple; (2) 3 pt. of preservative and I gal. of water/cwt. of raw pulped strawberry; 
(3) $3 \mathrm{pt}$. of preservative and no water/cwt. of raw raspberries, loganberries and blackberries. The percentages of fruit in these three classes are respectively 87,89 and 97 . The concentrations of sulphur dioxide permitted in the pulps are 2000 p.p.m. for strawberries and raspberries and I500 p.p.m. for other fruit. Table I shows some figures for the ascorbic acid content of fruit pulps kept for 8 months.

\section{Table I. Retention of ascorbic acid in fruit pulps}

\begin{tabular}{|c|c|c|c|c|c|c|}
\hline \multirow[b]{2}{*}{ Fruit } & \multirow[b]{2}{*}{$\begin{array}{l}\text { Time of } \\
\text { storage }\end{array}$} & \multirow{2}{*}{$\begin{array}{l}\text { Average } \\
\text { ascorbic } \\
\text { acid con- } \\
\text { centration } \\
\text { in raw } \\
\text { fruit } \\
\text { (mg./g.) }\end{array}$} & \multirow[b]{2}{*}{$\begin{array}{c}\text { Fruit } \\
\text { in pulp } \\
(\%)\end{array}$} & \multicolumn{3}{|c|}{ Ascorbic acid in pulp } \\
\hline & & & & $\begin{array}{l}\text { Calculated } \\
\text { (mg./g.) }\end{array}$ & $\begin{array}{l}\text { Found } \\
\text { (mg./g.) }\end{array}$ & $\begin{array}{c}\text { Retained } \\
(\%)\end{array}$ \\
\hline Black currant & 8 months & $\mathrm{I} \cdot 75$ & 87 & $I \cdot 5$ & $I \cdot 05$ & 69 \\
\hline Black currant & 20 months & $\mathrm{I} \cdot 75$ & 87 & $\mathrm{I} \cdot 5$ & 0.65 & 43 \\
\hline Gooseberry & Unknown & 0.35 & 87 & 0.30 & 0.27 & 90 \\
\hline $\begin{array}{l}\text { Strawberry whole } \\
\text { fruit }\end{array}$ & 8 months & 0.49 & 89 & 0.44 & 0.39 & 88 \\
\hline Strawberry pulp & 8 months & 0.49 & 89 & 0.44 & 0.10 & 23 \\
\hline
\end{tabular}

The actual concentration of ascorbic acid in the fruit used was not known, and in column 3 of Table I I have had to use average figures taken from the literature. The figures in the last column for percentage retention may therefore be a little inaccurate, but they serve to show the order of retention of ascorbic acid. The low figure for strawberry pulp is probably due to the oxidation of much of the ascorbic acid during the pulping of the lightly cooked fruit; it will be noted that the percentage retention in whole, uncooked strawberries is much higher and that the percentage retentions in black currant pulped after a more severe cooking procedure are also higher.

Ascorbic acid is only too readily destroyed by oxidation, and this oxidation is stimulated by the presence of minute traces of certain metals, e.g. copper, and also by enzymes known as oxidases which are present in certain fruits and vegetables; the activity of these enzymes is destroyed by heat. The destructive effect of the oxygen of the air is well illustrated by some results obtained at the Campden Research Station by Adam (I94r). He examined a number of fruits and vegetables which had been canned with varying amounts of 'head-space'. This space between the top of the contents and the lid of the can is filled with a mixture of air and steam; the greater the space the greater the amount of oxygen available for oxidizing the ascorbic acid. Table 2 shows the results he obtained. There is a steady fall in the retention as the head-space increases. Some results obtained in our laboratory some years ago on the storage of fruit drinks illustrate the same point.

These fruit drinks contained about $40 \%$ of sugar and 600 p.p.m. benzoic acid as preservative and were ready for dilution in the normal way. They were kept for periods of IO-I8 weeks and sampled at intervals. When samples were drawn from the bottles for analysis the bottle was inverted once or twice in order to mix the contents. The results for the concentration of ascorbic acid are shown in Table 3. The figures in any one column A-F refer to one particular bottle; many samples were taken from bottle $\mathrm{A}$ 
of each kind of drink but only one sample from most of the other bottles. The results for lemonade syrup II and orangeade syrup I show that, as the head-space was increased by withdrawing samples, the concentration of ascorbic acid decreased on storage whereas in samples taken from unopened bottles examined at the same time it showed no loss. The orangeade syrup II, it is true, showed only a slight fall on sampling for the fourth time, and the lemonade syrup I also showed only a slight fall on sampling for the seventh time after 88 days.

Table 2. Retention of ascorbic acid in canned fruits and vegetables

\begin{tabular}{|c|c|c|c|}
\hline \multirow[b]{2}{*}{ Fruit or vegetable } & \multicolumn{3}{|c|}{$\begin{array}{c}\text { Percentage of ascorbic acid retained } \\
\text { Head-space }\end{array}$} \\
\hline & o-5 ml. & $25 \mathrm{ml}$ & $45 \mathrm{ml}$. \\
\hline Gooseberries (Keepsake) & 73 & 57 & 38 \\
\hline Gooseberries (Keepsake) & 91 & 65 & 49 \\
\hline Gooseberries (Careless) & 80 & 68 & 44 \\
\hline Loganberries & 100 & 94 & $\longrightarrow$ \\
\hline Loganberries & $8 r$ & 71 & 66 \\
\hline Blackberries (cultivated) & 98 & 75 & 73 \\
\hline Blackberries (hedge) & 88 & 68 & $5^{6}$ \\
\hline Peas (Surprise) & 70 & 59 & 50 \\
\hline Peas (Lincoln) & 62 & 43 & 35 \\
\hline Peas (Charles I) & 66 & 52 & 38 \\
\hline Broad beans & 100 & 75 & 46 \\
\hline Stringless beans & 60 & 41 & 38 \\
\hline Carrots & 42 & 35 & 30 \\
\hline Parsnips & 81 & 47 & 39 \\
\hline Sprouts & 61 & 48 & 42 \\
\hline
\end{tabular}

In assessing the effect during storage of added preservative on the ascorbic acid in fruit products it is necessary to ensure that preservation has been satisfactory and that the head-space is as small as possible. The conclusions of the early workers that sulphur dioxide caused some destruction of ascorbic acid has been criticized on the grounds that these two conditions were not always satisfied. Allen, Barker \& Mapson (1943) noted this conclusion with some surprise, because they found that sulphur dioxide helped to preserve the ascorbic acid during the drying of cabbage. After a survey of the published work on the subject it is, I think, fair to say that sulphur dioxide causes little, if any, loss of ascorbic acid. At any rate, it is certain that sulphur dioxide, by preventing fermentation, preserves a large proportion of the ascorbic acid in fruit products which would otherwise be totally lost.

\section{Use of sulphur dioxide in the drying of fruits and vegetables}

Sulphuring, or the burning of sulphur to give an atmosphere of sulphur dioxide during the drying of fruit, has been practised for a long time to prevent the brown discoloration which otherwise occurs in peaches, apricots, and other fruits. It has been found that this treatment also helps to preserve vitamin C.

More recently Allen et al. (1943) used sulphite to preserve ascorbic acid during the drying of cabbage, and found that its use gave improved colour retention. The 
sulphur dioxide was applied by adding crystalline sodium sulphite $\left(\mathrm{Na}_{2} \mathrm{SO}_{3} \cdot 7 \mathrm{H}_{2} \mathrm{O}\right)$ to the scalding water. This neutral salt was used because sulphur dioxide and metabisulphite are acidic and therefore unsuitable for use with products containing

Table 3. Effect of storage and of increase in head-space by repeated sampling on the ascorbic acid content of fruit drinks

\begin{tabular}{|c|c|c|c|c|c|c|c|}
\hline \multirow{3}{*}{$\begin{array}{l}\text { Length of } \\
\text { storage } \\
\text { (days) }\end{array}$} & \multicolumn{6}{|c|}{ (Ascorbic acid mg./ $100 \mathrm{~g}$.) } & \multirow[b]{3}{*}{ Type of drink } \\
\hline & \multicolumn{6}{|c|}{ Sample bottles } & \\
\hline & A & B & $\mathrm{C}$ & $\mathrm{D}$ & $E$ & $\vec{F}$ & \\
\hline 8 & $8 \cdot 8$ & - & - & - & - & - & \multirow{8}{*}{ Lemonade syrup I } \\
\hline 14 & $8 \cdot 6$ & - & - & - & - & - & \\
\hline 30 & $7 \cdot 8$ & $8 \cdot 5$ & - & - & - & - & \\
\hline 32 & $8 \cdot 4$ & - & $8 \cdot 7$ & - & - & - & \\
\hline 43 & $8 \cdot 0$ & - & - & $7 \cdot 9$ & - & $\cdots$ & \\
\hline 44 & $8 \cdot 2$ & - & - & $8 \cdot 6$ & - & - & \\
\hline 88 & $8 \cdot 2$ & - & - & $8 \cdot 3$ & $8 \cdot 8$ & - & \\
\hline$\times 36$ & - & - & - & - & - & $8 \cdot 2$ & \\
\hline 12 & 6.0 & - & - & - & - & - & \multirow{6}{*}{ Lemonade syrup II } \\
\hline 18 & $5 \cdot 9$ & - & - & - & - & 一 & \\
\hline 34 & $4 \cdot 8$ & - & $\cdots$ & 一 & - & - & \\
\hline 36 & $4 \cdot 9$ & $6 \cdot 3$ & - & - & - & - & \\
\hline 47 & $3 \cdot 6$ & - & 5.9 & - & - & - & \\
\hline 80 & $2 \cdot 7$ & - & - & $6 \cdot 2$ & - & - & \\
\hline o & $12 \cdot 3$ & - & - & - & - & - & \multirow{5}{*}{ Orangeade syrup I } \\
\hline 4 & 11.7 & $\times 2.7$ & - & 一 & - & - & \\
\hline 8 & 10.2 & 一 & - & - & - & - & \\
\hline 9 & 一 & - & $11 \cdot 8$ & - & - & - & \\
\hline 53 & $2 \cdot 0$ & - & - & II 5 & 一 & 一 & \\
\hline 2 & 7.8 & - & - & - & - & - & \multirow{6}{*}{ Orangeade syrup $I$} \\
\hline 6 & $7 \cdot 8$ & $8 \cdot 8$ & - & - & - & - & \\
\hline 10 & $7 \cdot 1$ & $8 \cdot 1$ & - & - & - & - & \\
\hline $\mathrm{XI}$ & - & - & $9 \cdot I$ & - & 一 & 一 & \\
\hline 55 & $6 \cdot 2$ & - & - & $8 \cdot 3$ & $7 \cdot 1$ & 一 & \\
\hline 103 & - & - & - & - & - & - & \\
\hline
\end{tabular}

Table 4. Retention of ascorbic acid during different stages of the drying of cabbage, expressed as percentage of that in raw cabbage

(Allen et al. I943)

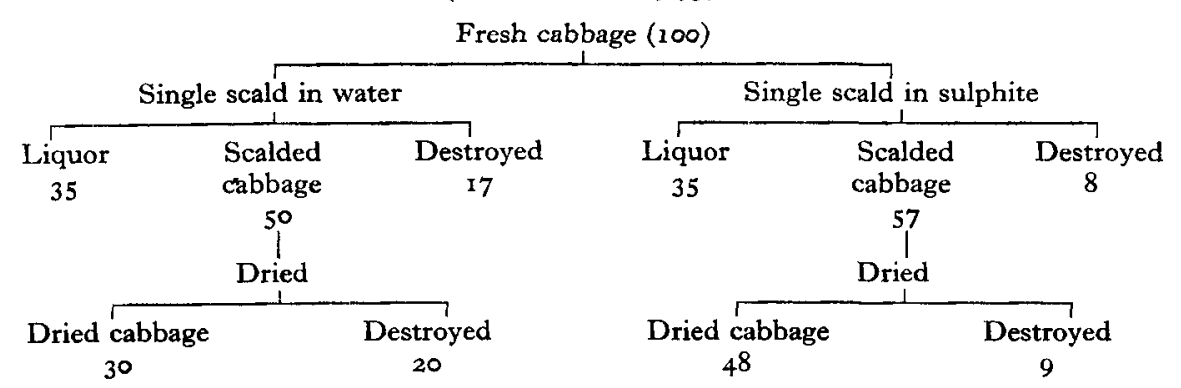

chlorophyll. The shredded cabbage was scalded for $4 \mathrm{~min}$. in one and half times its weight of boiling water. When $0.22 \%$ of crystalline sodium sulphite was added to the water, the scalded cabbage retained about 200 p.p.m. of $\mathrm{SO}_{2}$, the dried cabbage about ${ }_{5} 500$ p.p.m. and the reconstituted cooked cabbage about I00 p.p.m. Table 4 
summarizes the percentage retention of ascorbic acid in the various stages of the drying process; it will be seen that the use of sulphite in the scalding liquor results in improved retention.

I wish to thank the Directors of J. Lyons and Co. for permission to make this communication.

\title{
REFERENCES
}

Adam, W. B. (194I). Ann. Rep. Campden Res. Sta. 194r.

Allen, R. J. L., Barker, J. \& Mapson, L. W. (1943). F. Soc. chem. Ind., Lond., 62, $145 \cdot$

\section{The Preservation of Fruit-juice Products, with Special Reference to Nutritional Value}

\author{
By Vernon L. S. Charley, H. W. Carter and Co. Ltd., Bristol
}

The fruit-juice products with which this paper is concerned are all liquids, but their preservation is effected by various means. Some straight juices, e.g. apple and grape, can be filtered to a completely sterile condition; squashes which retain a proportion of the fruit tissue cannot be filtered, and must be preserved by other methods; some juices are particularly vulnerable to flavour alteration by heat and consequently pasteurization is not acceptable. In a review of this nature only the salient feature of each process can be given. As the preceding papers by Money (1947) and Baker (1947) have given considerable prominence to the chemical method which is common to the preservation of both fruit and vegetables and their juices, this paper will concentrate more especially on other widely used methods.

\section{Nature of changes occurring in fruit juices}

The changes which most generally occur in fruit juices in the unpreserved state fall into the following categories: ( $\mathrm{I}$ ) Yeast and bacterial action causing fermentation of normal or abnormal type, or acetification; (2) enzyme action, i.e. decomposition of pectin by naturally occurring enzymes which causes unsightly deposits; (3) changes due to interaction of many of the naturally occurring chemicals in the juice, and to some extent due to the presence of oxygen, which oxidizes flavouring compounds, ascorbic acid and the sulphur dioxide often added as a preservative.

The preservation of these products must take account of flavour, for this is one of the most important factors determining the palatability of a food product. Generally speaking, the factors which favour the retention of the true fresh-fruit flavours are those that tend to ascorbic acid retention.

Preservation of fruit juice products may be examined in three sections. Fruit, being a seasonable and perishable commodity, has to be processed during a restricted season and stored, generally in bulk, until needed for bottling or canning. This involves 